\title{
THEORY AND PRAXIS OF RELIGIOUS TOLERANCE
}

\author{
Igboin O. Benson* \\ http://dx.doi.org/10.4314/og.v12i 1.16
}

\begin{abstract}
More often than not, intolerance is extremely rejected in favour of tolerance simply because of the belief that the latter produces a better chance of inter-personal relationship in a pluralistic society. In this sense tolerance will mean to allow others to practise their religious belief without hindrance. While the term 'allow' carries a legal import i.e. authorisation, toleration means only the absence of objection rather than genuine approval of another's religious belief. It is therefore the argument of this paper that tolerance already divides between the powerful and the less-powerful, the privileged and the less-privileged. It is this inherent weakness in tolerance that makes the paper to insist on frank dialogue; truth-meeting-truth.
\end{abstract}

\section{Introduction}

Since our views of the future plays a significant role in our attitudes towards the immediate future, it is essential to ask whose view of reality is most accurate. When we fail to formulate concrete ideas, we leave the field to sects... who bank on their special eschatological system. In fact, once you understand their eschatology, you understand their doctrines.... we must find definite answers to such movements, even though we need to tolerate a certain amount of variation. ${ }^{1}$

Thomas Schirrmacher's thesis above speaks volume about tolerance. Certain delineations need to be made quickly in order to underscore what tolerance could possibly mean. First, emphasis is placed on asking, which for us, implies interrogation. An act of interrogation necessarily means that there is an interrogator and the interrogated. This being so, we concede that there is the concept of authority upon which he/she exercises power over the interrogated. Authority in loose conceptualisation defines some legal backing, a grundnorm upon which both parties depend to make their claims. But whether 
the grundnormis essentially agreeable to both is a matter for intellectual adjudication, but also more importantly, a practical problem.

The 'asking' also conveys the impression that the two competing views are in constant struggle to either eliminate the other or subsist and survive the crucibles foisted on it by the other. The leitmotif of the two views is ultimate reality defined from the prisms of the competing forces of the parties; it is a struggle to find whose view of the reality is "most accurate." In this process, we must admit that there are ordinarily three levels of reality: positive, comparative and superlative. As soon as a reality crosses from positive to comparative, there naturally begins a struggle to attain the superlative in a plural set up. Whether anyone will accept his/her reality to be conceived in less than the superlative in the context and contest of existential and eschatological (ultimate) struggle remains arguable. As Schirrmacher seems to portray, the comparative level of engagement is a critical stage of ascertaining the veracity or otherwise of other people's claims as well as one's. It is this stage that the chaff is sifted from the wheat, while the wheat is tolerated, the chaff is thrown away. This comparative stage is also relational on the basis of the tenor of individuals' beliefs being tested against some set principles. Hence the superiorisation and inferiorisation of values, doctrines and beliefs, which have been the thrust of tolerance, cannot be easily ruled out. But it is instructive that we appreciate that the dialectics of tolerance, especially religious tolerance (at both intra and inter levels) is complex and problematic.

Again, we come frontally with a separatist view of reality: Schirrmacher's point is that those who belong to a certain faith group are in a special class whose concept and view of reality and the future should form the basis of relation with those outside the group. This immediately conveys a sense of authority and grand superiority that evokes the spasm of reactions. Whose view of the future can truly be defined as authentic? What are the objective criteria to determine its authenticity? Who sets the criteria in the first instance? How acceptable are the criteria to others outside one's group? How do we reconcile discrepancies inherent in different sets of criteria by different faith groups in intra- and inter- religious 
relations in a pluralist setting? Is there any need of setting criteria at all if we are not sure of objective principles? Finally, can all the views of the future be truly authentic in a plural setting?

Consequently, this article interrogates the dialectic of the theory and praxis of tolerance, which resonate from the question of tolerance and the concept of tolerance. In this case, it is important for us to understand tolerance and why it is also usually being recommended as a sure way from violence that results from intolerance. In so doing, it is argued that tolerance is not enough because of the inherent problematique. Thus a focused, and modicum of dialogue is advocated, which in itself should be able to overcome the consequences of dialogueritis, but one that calls for greater frank and candid involvement in a pluralist society.

\section{The Concept of Tolerance}

The concept of religious tolerance at both intra- and inter- levels presupposes that there are various religious claims in the marketplace. It also predisposes that the context is pluralistic, which generally should stimulate equal rights, acceptance, accommodation, a live and let live situation despite the competitive forces of doctrines for the superlative. Within this context, "true tolerance (as a virtue, aligned with other virtues such as humility, respect and courtesy), by which each person or group of persons is entitled to defend his or her understanding of what is good for human beings by rational arguments, and to attempt to persuade others that it is, in fact, true," is further predicated "within a non-hierarchical framework of equality and non-discrimination." According to Gustav Mensching, "by tolerance, we mean - formally speaking religious freedom granted the individual to choose and to practice as he wishes." Formal tolerance will therefore imply that everyone within a system is reasonably free to pursue his/her religious belief without interference. As such, the state is neutral about religion in relation to articles 2 and 18 of the 1948 United Nations Universal Declaration of Human Rights (henceforth Declaration). ${ }^{3}$

Shaun A de Freitas' and Gustav Mensching's active meaning of tolerance may not underscore the whole gamut of what tolerance is. Jane Smith has shown that some conceptions of 
tolerance may be fairly passive. She examined its Latin etymology anglicized as tolerance to mean "to bear," "to suffer," to "endure."4 The leitmotif of "bearing a burden" as argued by Louis Hammann, points to the fact that human beings are being tolerated by God, as in "picking up and carrying" them. As such human beings should be able to tolerate one another as does God. Against the general belief that this may be a sign of passivity, Smith argues that "tolerance as suffering or enduring" carries a weight of active, though difficult response. To understand tolerance as "to put up with" or "to permit" as some scholars have argued, means that there is a disconnect between "tolerance and pain," which inherently goes contrary to its etymology. While tolerance in this context has to do with suffering, "toleration is not indifference, and cannot be insofar as indifference suggests lack of conviction." 5 This will mean that the degree of one's commitment to a religious belief is equal to the degree of suffering or pain one has to bear or tolerate.

Newman's distinction is apposite, according to which, toleration involves a broad spectrum: openness, application and also suggestive of passivity. Tolerance, on the other hand, is "a behavioral term, suggesting a response of activity in the concrete actions in which such openness is demonstrated." Newman sees toleration as a problem for dictatorial system whereas tolerance is "a difficult and painful business." "Toleration," EberhardTroeger argues, "is defined by laws and the courts." "Given this, we can say that toleration, though not neatly separated from tolerance, has legal tone, which is enforceable by one over the other.

Understood from the Western perspective, tolerance comes to assume the position of toleration, which means "permission or concession in relation to religious freedom." perspectival here, where it carries the weight of "permission" that does not necessarily imply "approval." MiroljubJevtic argued that even the Western conceptualisation of toleration is derived from Christianity rather than secular ideology. According to him, "consider toleration, for example, a civic virtue many today view as an offspring of secularism but whose absolutist roots are in Christianity and imbued in the very fate of Jesus." "Western countries did not only incorporate it into "their legal codex but also 
into cultural mores of everyday behavior." ${ }^{\text {"10 }}$ Really, Jevtic appears to interchange tolerance and toleration as many scholars do. This has created and continues to create confusion in tolerance discourse.

Tim Downs sees tolerance as glue that holds together the mosaic from disintegrating, but yet implies "sympathy and indulgence for beliefs or practices differing from or conflicting with one's own." 11 The fact being maintained is that one may not agree with another's religious views but indulge them. One can distinguish between negative and positive tolerance. The former being that one can understand another's religious beliefs and practices without sharing or accepting them whereas the latter, which modern pluralism apparently endorses means, in addition to understanding another's religious beliefs, one should also "accept them as equally valid approaches to life." 12

The idea of positive tolerance being linked with validity is critical in some sense. The concept of validity as underscored is limited to those who adhere to a certain belief rather than those who are enjoined to regard it as valid. For instance, the Christians hold that Jesus Christ is the Saviour of the world especially those who turn to him in faith. The validity of this doctrine rests indubitably on the Bible, defined as infallible and inerrant. However, the Muslims hold that Jesus Christ was just a prophet of God at best; a belief also entrenched in an infallible and inerrant scripture, the Qur'an. How does positive tolerance take place here? Tolerance for the Muslims will be that Jesus Christ the Saviour is limited to Christians and valid for them only. And that Jesus Christ as prophet is limited to Muslims and valid for them only. This, from the prisms of the Bible and Qur'an, will mean two different personalities of Jesus Christ that are difficult to relate with each other squarely. If this ends at the level of religious intellectualism, an intolerant situation may not be enacted, but a negative tolerance has been created. But this form of intellectualism contravenes the realities both believe Jesus Christ represents for them. The denial of either of the statements is considered prejudicial by one just as the other views it as invalidating his/her belief, and again just as its relative conception will impact adversely on the other's belief. 
Within the principle of tolerance, the problem of relativism and absolutism, according to which, the former gears towards tolerance and the latter dogmatism and judgementalism cannot be ignored. In the classical perception of the principle of tolerance, a person holds his religious or moral views exclusively as true while regarding opposing others are false. But he/she has respect for the person of the opponent and his/her rights to hold his/her views. Crisply put, one respects the person of the opponent, not his/her views or ideas of reality. Moreland and Craig evaluate this position to be absolutist because of its inconsistency with "normative and meta-ethical relativism and ethical skepticism."13 The modern sense of the principle of tolerance does not allow a person to pass value judgment on another's religious or moral view. But linking this with cultural relativism is problematic for the reason that there are different religions and cultures with differing ethical judgments. In its normative sense, being tolerant or intolerant depends on one's social [or religious] code. Examining the combinatorial relativism, which rejects moral judgment on another's "freely chosen understanding of the good life" or religious view, Moreland and Craig conclude that combinatorial relativism "is a vice and not a virtue" thus making the various forms of relativism problematic for the understanding of religious tolerance. ${ }^{14}$ That's why Smith points out that,

Newman argues that in one way the relativist is actually a critic of tolerance rather than a defender, insofar as that person by definition sees religious tolerance as a vestige of an absolutist understanding of religion. There is no reason not to be open to the beliefs of others when it is arguable that no one belief is substantially more true than that of another. If one subscribes to this argument, it would mean that those who hold a theologically "pluralist" position (setting aside the substantial arguments against the still popular tripartite categorization of theological positions vis-à-vis pluralism), seemingly more tolerant than the proposed "exclusivists" or 


\section{"inclusivists," are actually not demonstrating tolerance at all! ${ }^{15}$}

It appears that both classical and modern versions of tolerance are operative within legal frameworks that guarantee competing religious views to be accommodated. The equality envisaged and canvassed is not only theoretical but applicative and attainable by all. As Peter Hahne expounded, "tolerance is not a question of knowledge, conscience or deep personal convictions but is rooted in human dignity. We can have different opinions yet accept the other person as individual. Tolerance and love are two sides of the same coin." 16 The challenge this argument throws up is that the state has the responsibility of fostering genuine tolerance by being completely religiously neutral, thus providing a level playground for all religions. For the individuals, it is required that they should reciprocate the act of tolerance shown them by others. Mutuality of tolerance does not necessarily imply that one is weak or stupid as some have suggested, but that others are allowed to pursue without let what is religiously valid to them, because as the Chinese would say, "tolerant men are never stupid and stupid men are never tolerant." 17 One only hopes that the normative import of this is accepted by those who are religiously intolerant!

\section{The Paradox of Tolerance}

In this section, we review some literature on contemporary state of tolerance in different places to show that its praxis is problematic as well. The various legal instruments demonstrate the concept of tolerance. For instance, articles $2^{18}$ and $18^{19}$ of the Declaration explicitly guarantee religious liberty and freedom to change one's religion without let. Glenn Penner however identified that sharia concept is the most problematic challenge to the realisation of the Declaration globally. According to him, in any country or region where sharia is adopted as law, the idea of religious freedom automatically becomes difficult to observe and exercise. Even though there can be some scanty exceptions like Indonesia, it has been found that "the legislative process is at present 
strongly influenced by a conservative Islamic agenda." ${ }^{, 20} \mathrm{He}$ further asserts:

Not only did persecution begin because of religious intolerance, but it also took place in the home. Just as it divided the first family, loyalty to God often cuts families asunder. Let us not be surprised when in today's world we hear of, for example, young girls in Pakistan and India being shot to death by their relatives when they convert to Christ. I have met young teenagers in Ethiopia being driven from their homes into the streets to beg when they become believers. We are heartbroken when we discover that girls who have come to Christ in Muslim societies are sometimes forced by their fathers to marry Muslim men to guarantee that her children will be Muslims. $^{21}$

Thomas Schirrmacher and Kathleen McCall also argue that even though constitutions of many Islamic countries make provisions for religious freedom as a fundamental human right, conversion to another religion still attracts capital punishment whereas Muslims are free to proselytise. In many of these countries (Morocco, Pakistan, Iran, Saudi Arabia, Turkey, etc), Christians and Jews do not enjoy equal rights with their Muslim counterparts. The former are regarded as "second-class citizens" who must be "only tolerated and supervised" because "a Moslem citizen cannot be expected to endure and continually resist the missionary activity of other religions." 22 Christine Schirrmacher argues that "tolerance is not used here in the sense of a recognition based on equal rights, but rather in the sense of the toleration of an inferior."23 For the tolerated Jews and Christians, peace means being condoned as "wards" with inferior social, political, legal and economic status. As such they are constantly reminded that they can only attain full citizenship on the basis of conversion to Islam. Peace is not predicated on relationship of equality; as it seems, equality is a product of conversion, whose result may be peace. ${ }^{24}$ 
EberhardTroeger takes a historical excursus into the Islamic concept of tolerance towards Christians and Jews. Although Prophet Muhammad initially believed that his religion and those of the Jews and Christians were essentially agreeable, his rejection by the latter laid the foundation for disagreement, which led to their being regarded as "unbelievers." Consequently, they were treated as dhimmis, "protected people," who though were allowed to keep their faith, yet had to pay poll tax. As such they enjoyed far less rights than Muslims, and were only tolerated. ${ }^{25}$ Ergun and Emir Caner argue that even though caliph Umar was regarded as a very tolerant man, he indeed restricted Christianity and Judaism. Umar's protocol of protection for Christians read inter alia:

The protection is for their lives and properties, their churches and crosses, their sick and healthy and for all their co-religionists. Their churches shall not be used for habitation, nor shall they be demolished, nor shall injury be done to them or to their compounds, or to their crosses, nor shall their properties be injured in any way. There shall be no compulsion for these people in the matter of religion, nor shall any of them suffer any injury on account of religion. $^{26}$

The Umar's law of mercy can be compared with his Pact with Christians, according to which, they

shall not build, in our cities or in their neighborhood, new monasteries, Churches, convents, or monks' cells, nor shall [they] repair, by day or by night, such of them as fall in ruins or are situated in the quarters of the Muslims; shall not manifest religion publicly nor convert anyone to it.... [Christians] shall not prevent any of [their] kin from entering Islam if they wish; shall show respect toward the Muslims, and shall rise from seats when [Muslims] wish to sit"; "shall 
not display crosses or books in the roads or markets of the Muslims.... [They] shall use only clappers in churches very softly. ${ }^{27}$

These have continued to guide the relationship between Christians and Muslims even in the $21^{\text {st }}$ century as they are being interpreted and re-interpreted, especially by the radical Islamic sects. Turkey has strict laws against other religions. As BehnanKonutgan observes, "to be a Turk, means to be a Muslim. Other religions are not accepted and tolerated." ${ }^{28}$ Even though Saudi Arabia claims to be religiously liberal, in practice it does not tolerate other religions. A US report says that

Freedom of religion does not exist. Islam is the official religion and all citizens must be Muslims. The Government prohibits the public practice of other religions. Private worship by non-Muslims is permitted. ... Under Shari'a (Islamic law), upon which the Government bases its jurisprudence, conversion by a Muslim to another religion is considered apostasy. Public apostasy is a crime punishable by death if the accused does not recant. ${ }^{29}$

In Sri Lanka, non-Buddhists are not really tolerated. Article IX of the 1978 constitution regards Buddhism as "the foremost place" and empowers the state to "protect and foster" it. Although this runs contrary to Article $\mathrm{X}$ which grants every citizen the freedom to adopt and manifest publicly or privately the religion of their choice, the stark reality however is that government does not only legally discriminate against non-Buddhists, but also tolerates violence against religious minorities. In a celebrated case in summer 2003 when a group of Catholic nuns sought legal incorporation for their religious order to provide educational and other social services within their faith, the Supreme Court held that "the constitution does not recognize a fundamental right to propagate a religion" and that "the propagation of and spreading of Christianity ... would impair the very existence of Buddhism" as the protected religion. Even 
when the nuns appealed to the UN, which interpreted it as a violation of the international law, the Sri Lankan Supreme Court ruled that the UN's decision in contra to its constitution has no binding authority on the country. ${ }^{30}$

Iran believes that modern conceptualisation of racism is not based on inequality between races, but on culture, nationality and religion, a position the US rejects on the basis of the fact of distinction between racism and religion. ${ }^{31}$ Article 12 of the Iranian constitution recognises Jews, Christians and Zoroastrian Iranians as religious minorities. However, Baha'i (founded by Baha'u'llah in Teheran in the middle of the $19^{\text {th }}$ century) does not enjoy the status of the dhimmis. This is because Muslims regard Muhammad as the last prophet, thus putting Baha' $i$ faith outside the pale of protection. $^{32}$ To be sure, this question of tolerance resonates between Christians and Muslims, namely that the Muslims accepted the Jewish and Christian religions whereas they reject Islam. The argument of Jews and Christians is simply because they believe their revelations had been completed before the rise of Islam; argument Muslim apologists do not accept to be valid, and now could not be extended to the Baha'i either. ${ }^{33}$ The same thing can be said to have happened between Jews and Christians. The Jews reject Jesus as the Messiah, which the Christians accept as the fulfilment of the Old Testament as a whole.

The idea of new conceptualisation of racism defined in terms of religion is instructive even though the US may disagree. One illustration will clarify this. The Danish cartoon saga (in which Muhammad wears a bomb-shaped turban, and another shows him as an assassin) raised a lot of dust in the Muslim world. The cartoon was viewed as insulting the prophet of Islam, which verdict was death. According to Abdul Aziz IbnBaz, the most respected authority and vociferous Saudi Islamic theologian,

Different sources tell us that whoever insults Allah's prophet (Muhammad) or abuses his name must be killed .... All Muslim theologians and groups - like al-Shafi'I [the father of Islamic jurisprudence], Malik [a jurist of the early Islamic times] etc. - 
agree on the opinion that whoever insults Allah's prophet must be killed. And: Insulting Muhammad can have different forms ... whoever compares Allah's prophet with an animal is an outlaw and an unbeliever, his blood and his belongings are no longer protected. ${ }^{34}$

However, there was no single protest over a cartoon published by an Egyptian newspaper, Saut al-Masa where "the Egyptian cartoonist has drawn a picture of a cock with a human head and has given it the subtitle: 'This is Muhammad, my Lord, who was married to nine wifes' (sic). ... This is a clear allusion to Allah's prophet ...."35 It is argued that since the cartoon was published by a Muslim in a Muslim newspaper in a Muslim country, it is tolerable, but if it had been in the West or elsewhere, there would have been massive protests. The same can be said about the desecration and destruction of the tombs of the Muslims saints in Timbuktoo, particularly the mausoleum of the Imam Moussa al-Khadin, which for long has become "a world heritage under the protection of UNESCO and accorded pride of place in African patrimony.",36

Again, the US ambassador to Libya,Ambassador J. Christopher Stevens and three others were killed on the reason that some Americans released an obscure film that portrayed Prophet Muhammad in bad light. This film was reported to have been written, produced and directed by NakoulaBasseleyNakoula, an Egyptian-American Coptic Christian. ${ }^{37}$ Sam Bacile also claimed authorship and added that it was sponsored by some Jewish business men. The controversies trailing the film have made it hard to trace the makers. ${ }^{38}$ The question of tolerance here does not have anything to do with the producer of the film who, as has been shown earlier, does not represent the spirit of tolerance preached by his faith, but more crucially on the killing of innocent people, who might not have been related in any way with the producer. Such other acts as those of Pastor Terry Jones, accused of burning a copy of the Qur'an in Florida in 2010, Salmon Rushdie's Satanic Verses in 1989, the Danish cartoon saga in 2005, the call for deportation of all Muslims from Europe, the Crusades (1095-1291), which has been termed 
"Christian Jihad," a retaliatory act provoked by the killing of about 7000 Christians on the way to worship in Jerusalem, etc. raised critical questions of tolerance in Christianity as well. ${ }^{39}$

The Organisation of Islamic Conference (OIC) has repeatedly made it known that Islam is unique and should be isolated from Western intolerance. ${ }^{40}$ The evolution of "Universal Islamic Declaration of Human Rights of 1981," “1990 Cairo Declaration of Human Rights," and "Arab Charter on Human Rights" of 15 September 1994, is a step towards vitiating the 1948 Declaration, which some Islamic countries believe should be revised. These Islamic Declarations theoretically hold the equality of all human beings, but specific provisions and conditions for enjoying them show that they are Islam-prone. All of them believe that sharia is exclusively the basis of enjoying them despite the fact that they widely acclaim that "there is no compulsion in religion." 41 This, Hans-Peter Raddatz, called "Shariatising," that is, "a movement pushing for existing legislation of the Sharia." 42 In addition, the hadiths also in many instances pronounce very harsh punishments on non-Muslims. ${ }^{43}$

\section{Tolerance and Theological Fault Lines}

For some time now, the Organisation of Islamic Conference (OIC) has been advocating the enforcement of an international law against defamation of religion. It argues that not only Islam should be isolated from defamation, but all world religions. This is because religion is not only sensitive, but also reaches the core of human existence. This call has deep theological issues that need to be handled with total commitment without also compromising the integrity one's faith. As shown earlier, the histories of the development of revelations as contained in the sacred texts of Judaism, Christianity and Islam do not allow for superimposition of extempore revelation. Each revelation is believed to be complete on its own as well as independent of one another to a large extent except for Christianity that believes it fulfils the Old Testament. That being the case, the irreconcilable texts should be viewed with utmost caution especially on the basis of historical development. We illustrate this point with a few examples. 
Responding to the OIC advocacy for the observance of a global law of defamation of religion, Raymond Ibrahim emphasises the theological task and challenge before the Muslims. According to him, if by defamation is meant "to blacken another's reputation" and "false or unjustified injury of a good reputation of another," it will mean that such a law will ban the existence of Islam. Defamation, to Muslims, means anything that insults or repudiates Islam or offends the sensitivity of Muslims. If this law is implemented, he maintains, it will mean that the OIC has agreed that slanderers on another's religion should be banned. "What, then, do we do with Islam's core religious texts - beginning with the Qur'an itself, which slanders, denigrates and blackens the reputation of other religions?" To be sure, Surah 5: 73 refers to Christians as infidels because of their belief in the Trinity while Surah 9: 30 curses them for upholding the belief that Christ is the Son of God, whereas Allah is not begotten nor does he beget. Some hadiths regard the cross worn by Christians as idolatry. How would the Catholic Christians manage the religious sensitivity provoked by an authoritative Qur'anic exegete, IbnKathir who posits that Muhammad in paradise is married to, and enjoying sex with, Virgin Mary ? $^{44}$

The idea of Jesus Christ being the "herald of Islam" or "a precursor to Mohammad" and that he is being falsely worshipped since he is not a saviour will have to be interrogated. To be sure, the disciples of Jesus Christ have been accused of promoting the worship of Jesus in order to distort his "originally Islamic" message. This makes Christian revelation as contained in the Bible a "falsified text," which should be redacted in light of the Qur'an. ${ }^{45}$ The denial of Christ's crucifixion (Qur'an 4: 157), the apostleship of Jesus rather than the saviour (Qur'an 4: 171), the creation of Jesus in opposition to his eternity (Qur'an 3: 59), etc. are theological areas that tolerance, even in its positive sense may not be able to resolve, particularly when upholding the inalterability, infallibility and inerrancy of the Qur'an. ${ }^{46}$ Several Muslim publications have portrayed Christians not only as idolaters, polytheists but also atheists and unbelievers. ${ }^{47}$

Unfortunately, these theological grey areas have assumed widespread political platform and 'religious racism.' When a non- 
Muslim does anything interpreted as offensive to Islam, it is generally held that Christians are responsible. The West has been christened Christian despite the fact that Christians argue that the West itself is undermining their faith with avid pursuit of secularism and post-Christianity. Ergun and Emir Caner write: "Europe is not Christian, and no society any more diverse in religion than that in North American." ${ }^{48}$ In the West, for instance, a lot of writings against Christianity have been had, and still being published, apart from those from the Arab world. The supposed marriage of Jesus by Harvard Divinity School professor Karen L. King's The Gospel of Jesus' Wife, Dan Brown's novel The Da Vinci Code, among other controversial opinions even about the historicity of Jesus Christ do not readily result in physical violence in contemporary society.

The same idea is replicated in Nigeria. Most southerners are perceptively linked to the West and most northerners Arab. ${ }^{49}$ For example, concerning the film mentioned above in which US Ambassador and three others were killed, the leader of Islamic Movement in Nigeria Sheikh Ibrahim Zakzaky describes the Goodluck Jonathan's government as stooge of America that only carries out the commands of the West. According to him,

Our message to the stooges of America is that our protest shall surely take place. So, the blood thirsty stooges who serve American interest shall have the chance to kill. We are ready to die for the Prophet, and we want you to show that you are enemies of Prophet by killing his lovers. Our common slogan is "LibbykaRasulallah." This is the symbol of unity, so all Muslims shall express their concern with us. One is either with the Prophet or with the enemies. ${ }^{50}$

These are really strong mobilising words, calling out Muslims in Nigeria to fight against innocuous Christians (tagged enemies) who do not know or gain from the contentious movie. One only hoped that more lives would not be lost in addition to the devastation being currently experienced from the Islamic sect called Boko Haram education is evil! Wole Soyinka observes that such protests are 
"largely directed against the innocent, since the originating hand is usually, in any case, beyond reach.",51

The fore-going naturally leads to the question whether tolerance is enough. Edward Hulmes forcefully answers that "tolerance and understanding are insufficient even when elevated and institutionalized into an ideological commitment." ${ }^{, 52}$ Can one be tolerant with an intolerant other $?^{53}$ May be tolerance expresses weakness and resignation of the intolerant or perhaps it is completely absurd. ${ }^{54}$ This is because tolerance has been understood thus far in three principal ways: dialectic of master-slave in which one superintends and another subordinated, i.e. perquisite; fanciful ideology, which is skewed and suspicious; and expression of impatience and irrationality, which exudes violence. As such Elizabeth Kendal argues, what is necessary as a prophylaxis is "more dialogue, not less." 55

\section{The Possibilities of Dialogue}

It has been suggested that the obvious shortcomings of tolerance have intensified the need for dialogue. ${ }^{56}$ But it is also being observed that dialogue is becoming abused because of distortion of its meaning, scope and prerequisites. Dialogue has been equated with meetings, debates and negotiations, especially in Nigeria where inter-religious conflict is commonplace. Some have made it assume a simplistic posture such that its supposed regularity is confused with its less effect on society. ${ }^{57}$ This is why the wise counsel that "dialogue should not mutate into a "dialogueritis," [i.e.] an illness described as suffering from too much dialogue at a time" should be urgently taken into consideration. ${ }^{58}$ However, to overcome the problematique of tolerance and dialogueritis, Soyinka suggests that "there must be dialogue of frank, mature minds. Instant, comprehensive solutions do not exist, only the arduous, painstaking path of dialogue, whose multi-textured demands are not beyond the innovative, as opposed to the emotive capacity, of cultured societies." $" 59$

Although the argument has been that there is the need to urgently move through the dialogue of mind (involving selfredefinition and identity geared towards mutual understanding rather 
than conversion); dialogue of life (where real issues of life are identified in the dialoguing communities and tackled frankly, boldly and courageously) to dialogue of hearts (which depicts mutual respect for one another's religion and the affirmation of life in the face of common life-threatening challenges), ${ }^{60}$ it seems to us that if any of the stages is impatiently hurried through, the desired effects cannot be got because each of the stages is a function of the quantum of tolerance displayed. This is the situation in Nigeria and elsewhere. As Soyinka expounded above, dialogue requires frankness and candour so that teething areas of disagreement can be earnestly interrogated. And this requires mature minds that must first and foremost be prepared to "unlearn their misinformation" ${ }^{\text {"61 }}$ previously held about other people's religious beliefs. Of course this is where the problem lies: realistically open-minded partners, competent in their belief and capable of admitting the shortcomings therein with integrity on the basis of truth-meeting-truth.

The point is that frankness requires 'grace' to admit that not all aspects of a religious belief can pass through the 'eye' of comparative stage to the superlative. The challenge has been that some religious beliefs have jumped the scrutinising sift or filter and declared themselves superlative. But if we must not pursue religious truth by violence as the world is currently undergoing, which is the black spot on Islam, there is the need for this kind of dialogue of theology and historicity of religious claims. The urgency of this rests on the fact that the "golden age of Islam" was when it stopped its spread by jihad and resorted to intellectualism.

They had come out of the Arabian Peninsula in the 7th century, carrying Islam from Morocco to faraway Indonesia. In the process, they overran the Byzantine and Persian empires, then crossed the Strait of Gibraltar to Iberia, and there they fashioned a brilliant civilization that stood as a rebuke to the intolerance of the European states to the north. Cordoba and Granada were adorned and exalted in the Arab imagination. Andalusia brought together all that the Arabs favored - poetry, glamorous 
courts, philosophers who debated the great issues of the day. ${ }^{62}$

Ergun and Emir Caner are worth quoting to reassess Islam through the eyes of history, and ask frankly as didhistorian Bernard Lewis in his 2002 book What Went Wrong?

Baghdad flourished in wealth and scientific learning.... Inventions included the clock pendulum, the magnetic compass, and algebra. Baghdad had an unmatched library that housed writings from Aristotle and Plato. In medicine, Muslims were the first to use anesthesia in surgery, the first to discover that epidemics spread through contact and by air, developed the first ambulatory hospital (carried on a camel's back), and separated pharmacology from medicine. The energy of Muslim militancy was directed toward intellectual discovery. ${ }^{63}$

These must challenge both Christians and Muslims to reassess themselves in light of contemporary global religious and security challenges. While it may be argued that monotheistic religions are not less violent than polytheistic ones as demonstrated in the interaction between Buddhism, Hinduism, Islam and Christianity in India, Sri Lanka as well as Pakistan, one can say that African Religion particularly in Africa is not as violent as Islam and Christianity. This perhaps may result from the fact that it does not have a codified sacred text as Hinduism, Christianity, Islam and Buddhism, which draw from them to justify violence. ${ }^{64} \mathrm{~A}$ lot of insight needs to be drawn from this in genuine dialoguing.

First, there is a lesson to learn from African Christianity. Rather than take up arms physically against the Amorites, Jebusites, etc. they perceive them as spiritual forces militating against their lives. So they pray for deliverance from these wicked powers and principalities. What is suggestive here is that instead of resorting to physical violence Christians and Muslims as well as other adherents of various religions should interact with their scriptures from this perspective. As Adrian Pabst captures it, 
Both Islam and Christianity must first and foremost call for a restoration of limits on violence and war. To this effect they must repudiate all those traditions which sanctify the indiscriminate violence of war without limits. Muslims cannot tolerate or excuse those who wage offensive jihad and commit suicide bombings in its name. ${ }^{65}$

Second, what follows immediately is that such dialogue must repudiate the assumption of what we may call 'human omnipotence,' in which adherents believe and behave as if they have power over life and death, thus killing in the name of God. The idea this conveys is that a God who needs to be fought for or defended by human arms is less than an omnipotent one in the true sense of the word. To assume religious extremism clothed in the garb of martyrdom or honour-killing is not only explicitly blasphemous against an omnipotent God but also justice and love such a God necessarily should represent. ${ }^{66}$ Intra- and inter- theological dialogues should be called in this direction.

Third, genuine dialogue should entail a reassessment of the real life issues that confront the people. The following question is relevant: how have the governments headed by some Muslims and Christians benefited the Muslim and Christian masses, apart from the psychological satisfaction that a person belonging to one's religion is at the helms of affairs? The core probing here is that the supposed 'notoriety' and 'incurability' of religiosity is more negatively demonstrated, especially in Africa.

Fourth, to what visible extent has Nigeria's foreign relations with the Arab and Western worlds helped to ameliorate the suffering of the Nigerian masses? This is pertinent because Muslims and Christians react to what happens outside Nigeria in the country sometimes violently against the innocent people. The question is: what has affiliation with Arab world done to ameliorate the plight of the well over seven million almajirai in northern Nigeria ${ }^{67}$ whose destiny hangs on the balance or the West to the predicament of the Christian poor? One dare suggests that there is the need to mobilise 
Christians and Muslims for social action against the common enemies of the masses, e.g. corruption, poverty, ignorance, disease, mortality rate, etc.

Fifth, both Christians and Muslims should courageously face the fact that their faiths have some irreconcilable areas even though they reach the depth of their being. Frankly, dialogue cannot resolve such deep theological differences that history has already stamped on each religion. But dialogue can make everyone free to propagate his/her faith in a pluralistic society. The freedom of religious belief as prescribed by a constitution confers on all citizens to pursue their belief without let. To restrain the Christians by constant attacks (as being done in northern Nigeria, for instance) does not only portray the attackers in bad light but also appears to go the way of human omnipotence, which in all ramifications is a by-product of religious intolerance and impotence of a divinity.

\section{Conclusion}

We have argued that tolerance is a problematic concept in theory and practice. Intolerance, which is widely acclaimed to be its opposite, is less problematic because of the fact that it can be easily deployed physically. In the case of tolerance, the acceptance or rejection of the validity of another's religious claims lies deeply in the mind, the psyche. Even though it may not readily result in violence as in intolerance, the prejudice that it evokes makes it potentially prone to violence. This is because it hinges on the fact of authorisation: one allowing or disallowing the other from holding some religious belief. The fact of authority in tolerance, even from its pristine conceptualisation, 'burden bearing' makes tolerance, even in its positive stride weak in both theory and praxis. The nature of religious truth cannot be scientifically processed by the dint of tolerance because of 'rigging' it from comparative to superlative level. This can only be achieved through the gristmill of dialogue, which periscope is to condescend to understand one another's truth.

The fore-going does not actually solve the deep theological differences between religious claims. But an honest seeker of truth would appreciate that historicity of scriptures should not be based on democracy but by the truth-content of particular religions. For 
instance, if Christ fulfilled the Old Testament prophecies concerning him, he does not point to the future for further fulfilment. He is fulfilment-personified demonstrably observed in the Christ's events. If the Jews await the Messiah, it does not vitiate Christ's fulfilment of the prophecies concerning him. But if Muslims view Christ as a prophet rather than a saviour, then the Old Testament, which they all subscribe to, becomes the judge. This actually requires an objective, dispassionate and honest approach. It is here that we can proceed to view the future Schirrmacher so passionately talks about, i.e. on the basis of truth-meeting-truth.

*Igboin O. Benson, Department of Religion \& African Culture, AdekunleAjasin University, Akungba-Akoko, Ondo State, Nigeria, Email: bensonigboin@gmail.com 


\section{References}

Thomas Schirrmacher, Hope for Europe: 66 Theses, available at http://www.vtr-online.de

${ }^{2}$ Shaun A de Freitas, "Freedom of conscience, medical practitioners and abortion in South Africa" International Journal for Religious Freedom, 4/1, 2011, 82.

${ }^{3}$ Gustav Mensching, Tolerance and Truth in Religion.The University of Alabama Press, 1955, 3.

${ }^{4}$ Jane I. Smith, "Religious Tolerance" Journal of Islam and Christian Muslim Relations, available at http://macdonald.hartsem.edu/

${ }^{5}$ Smith, "Religious Tolerance" Journal of Islam and Christian Muslim Relations, available at http://macdonald.hartsem.edu/

${ }^{6}$ Smith, "Religious Tolerance" Journal of Islam and Christian Muslim Relations, available at http://macdonald.hartsem.edu/

${ }^{7}$ EberhardTroeger, "Do Muslims face intolerance in Germany?" Journal of the Institute of Islamic Studies, 1/2008, 14.

${ }^{8}$ Smith, "Religious Tolerance" Journal of Islam and Christian Muslim Relations, available at http://macdonald.hartsem.edu/

${ }^{9}$ MiroljubJevtic, "Politology of Religion" Politics and Religion, 3/2, 2009, 280.

${ }^{10}$ MiroljubJevtic, "Politology of Religion," 281.

${ }^{11}$ Tim Downs, Finding Common Ground, Chicago: Moody Press, 1999, 27.

${ }^{12}$ Downs, Finding Common Ground, 28.

${ }^{13}$ J. P. Moreland and William L., Craig, Philosophical foundations of a Christian worldview. Illinois: IVP Academic, 2003, 415-416.

${ }^{14}$ Moreland and Craig, Philosophical foundations of a Christian worldview, 416.

${ }^{15}$ Smith, "Religious Tolerance" Journal of Islam and Christian Muslim Relations, available at http://macdonald.hartsem.edu/ ${ }^{16}$ Troeger, "Do Muslims face intolerance in Germany?," 19.

17 Cited in Benson O. Igboin, "The doctrine of ahimsa (Nonviolence) in Indian religions: Impact and relevance in contemporary 
society" Long Essay submitted to Edo State University, Ekpoma, Nigeria, 1997, 83.

${ }^{18}$ Article 2: "Everyone is entitled to all the rights and freedoms set forth in this Declaration, without distinction of any kind, such as race, colour, sex, language, religion, political or other opinion, national or social origin, property, birth or other status. Furthermore, no distinction shall be made on the basis of the political, jurisdictional or international status of the country or territory to which a person belongs, whether it be independent, trust, non-self-governing or under any other limitation of sovereignty."

19 Article 18: "Everyone has the right to freedom of thought, conscience and religion; this right includes freedom to change his religion or belief, and freedom, either alone or in community with others and in public or private, to manifest his religion or belief in teaching, practice, worship and observance."

${ }^{20}$ Glenn M. Penner, In the shadow of the cross: A biblical theology of persecution and discipleship, Bartlesville: Living Sacrifice Books, 2004, 20.

${ }^{21}$ Penner, In the shadow of the cross, 29.

${ }^{22}$ Thomas Schirrmacher and Kathleen "Wally" McCall, A Life of Transformation - From Politician to Good Samaritan: A Festschrift For Colonel V. Doner, Hamburg: ReformatorischerVerl. Beese, 2002, 12.

${ }^{23}$ Christine Schirrmacher, Islam - An introduction, Germany: Bonn, 2011, 74.

${ }^{24}$ YohananFriedmann, Tolerance and coercion in Islam: Interfaith relations in the Muslim tradition, Cambridge: Cambridge University Press: 2003, 37.

${ }^{25}$ Troeger, "Do Muslims face intolerance in Germany?," 14.

${ }^{26}$ Ergun M. Caner and Emir F. Caner, Unveiling Islam: An insider's look at Muslim life and beliefs, Kaduna: Evangel Publishers, 2002, 69.

${ }^{27}$ Caner and Caner, Unveiling Islam, 175. 
${ }^{28}$ BehnanKonutgan, "Christians still second-class citizens under Turkish secularism: Decades of experience of a Turkish Christian leader" International Journal for Religious Freedom, 2/1, 2009, 102.

${ }^{29}$ Thomas Schirrmacher, The persecution of Christians concerns us all: Towards a theology of martyrdom, Germany: Bonn, 2008, 116.

${ }^{30}$ See "Sri Lanka religious freedom profile" International journal for religious freedom, 1/1, 2008, 16-17.

${ }^{31}$ Elizabeth Kendal, "Religious Liberty Trends 2007-2008" International journal for religious freedom, 1/1, 2008,

${ }^{32}$ Thomas Schirrmacher, "Iran: Suppression of religious freedom and persecution of religious minorities"International journal for religious freedom, 2/1, 2009, 117.

${ }^{33}$ Friedmann, Tolerance and coercion in Islam, 15-16.

${ }^{34}$ Petra Uphoff, "Islamic human rights under scrutiny" Journal of the institute of Islamic studies, vol 1, 2006, 35.

${ }^{35}$ Uphoff, "Islamic human rights under scrutiny," 35.

${ }^{36}$ Wole Soyinka, "Religion against humanity" being a paper presented as a member of UNESCO's International High Panel, at the 2012 Conference on the Culture of Peace and Non-Violence, United Nations Headquarters, New York, September 21, 2012.

${ }^{37}$ DisuKamor, "The anti-Islam film and Islamophobia" retrieved from www.mpac-ng.org

${ }^{38}$ FouadAjami, "Why is the Muslim world so easily offended?" Washington Post, September 14, 2012.

${ }^{39}$ Caner and Caner, Unveiling Islam, 73-75.

${ }^{40}$ See Ikenga K. E. Oraegbunam, "International Relations under Islamic Law: A Critique of its Implications for Nigerian Constitutional Democracy", NnamdiAzikiwe Journal of Political Science, Vol. 3 No. 2, 2012, 397-410. See also https://www.academia.edu/12352856/International_Relations_under _Islamic_Law_A_Critique_of_its_Implications_for_Nigerian_Consti tutional_Democracy.

${ }^{41}$ Thomas Schirrmacher, Racism: With an essay by Richard Howell on Caste in India, Canada: World Evangelical Alliance, 2011, 4142. 
${ }^{42}$ Hans Zehetmair (Ed). Islam in tension between conflict and dialogue reviewed in Journal of the institute of Islamic studies, 2, 2006, 43.

${ }^{43}$ Christine "Schirrmacher, Apostasy and sharia”http://www.kuyper.org/main/uploads/volume_15_no_1.pdf

${ }^{44}$ Raymond Ibrahim, "How religious defamation would ban Islam" http://shoebat.com/2012/10/03/raymond-ibrahim-how-religiousdefamation-laws-would-ban-islam/

${ }^{45}$ Friedmann, Tolerance and coercion in Islam, 15-16.

${ }^{46}$ Caner and Caner, Unveiling Islam, Chapters 14 and 15.

${ }^{47}$ Schirrmacher, The persecution of Christians concerns us all, 64.

${ }^{48}$ Caner and Caner, Unveiling Islam, 211.

${ }^{49}$ Ikenga K. E. Oraegbunam, "Human Rights Jurisprudence under Islamic Law: A Critical Review of Contending Conceptions”, Sacha Journal of Human Rights, Vol. 2 No. 1, 2012, 68. See also https://www.academia.edu/26381353/HUMAN_RIGHTS_JURISPR UDENCE_UNDER_ISLAMIC_LAW_A_CRITICAL_REVIEW_OF_ CONTENDING_CONCEPTIONS

${ }^{50}$ Ibrahim

Zakzakyhttp://islamicmovement.org/index.php?option=com_content $\& v i e w=$ article $\& i d=451$ : pictures-of-protest-against-us-made-antiislam-video-held-in-zaria\&catid=41:frontpage

${ }^{51}$ Soyinka, "Religion against humanity"

52 Edward Hulmes, Commitment and Neutrality in Religious Education, London: Geoffrey Chapman, 1979, 5.

${ }^{53}$ Troeger, "Do Muslims face intolerance in Germany?," 19.

${ }^{54} \mathrm{John}$ Warwick Montgomery, TRACTATUS LOGICOTHEOLOGICUS, Bonn, 2005, 45.

${ }^{55}$ Kendal, “Religious Liberty Trends 2007-2008,” 19.

${ }^{56}$ Ikenga K. E. Oraegbunam, “Jurisprudential Review of the

Controversies on the Nature of Islamic Law", African Journal of Law and Criminology, Vol. 1 No. 2, 2011, 114. See also

https://www.academia.edu/26378947/A_JURISPRUDENTIAL_REVI EW_OF_THE_CONTROVERSIES_ON_THE_NATURE_OF_ISLAM IC_LAW 
Benson O. Igboin, "The concomitance of religious conflicts in Nigeria: Secularity, tolerance and dialogue”, Human views on God - Variety not monotony: Essays in honour of Ade P. Dopamu, eds. A. K. Chepkwony and P. M. J. Hess, Eldoret: Moi University Press, 2010.

${ }^{58}$ Zehetmair (Ed). Islam in tension between conflict, 43.

${ }^{59}$ Soyinka, "Religion against humanity"

${ }^{60}$ Mahan Mirza, "Christian-Muslim relations in Pakistan" Journal of Islam and Christian Muslim relations, http://macdonald.hartsem.edu/

${ }^{61}$ L. Swidler, Jewish Monotheism and Christian Trinitarian Doctrine: A dialogue by PunchasLapide and JurgenMoltmann, Philadelphia: Fortress Press, 1981, 7.

${ }^{62}$ Ajami, "Why is the Muslim world so easily offended?"

${ }^{63}$ Caner and Caner, Unveiling Islam, 72.

${ }^{64}$ Natalia Vlas "Is religion inherently violent? Religion as a threat and promise for the global security" Politics and religion, 4/2, 2010, 300.

${ }^{65}$ Adrian Pabst, "Unholy war and just peace: Religious alternatives to secular warfare” Politics and religion, 3/2, 2009, 225.

${ }^{66}$ Benson O. Igboin, "The God Question and Man's Claim to Omnipotence," International Journal of Philosophy 17/1 (January 2016): 93-107.

${ }^{67}$ Muhammad S. Abubakar, "Islam and Peace-building in West Africa" lecture delivered at The Samuel L. and Elizabeth Jodidi Annual Lecture at Weatherhead Center for International Affairs, Harvard University, USA, $9^{\text {th }}$ October, 2011. 